\title{
OPTIMUM CONDITIONS FOR GROWTH IN LIQUID MEDIUM OF OSCILLATORIA FORMOSA BORY USED AS THE PRINCIPAL FOOD IN LABORATORY CULTURE OF INTERMEDIATE HOSTS FOR SCHISTOSOMOSIS AND FASCIOLOSIS
}

\author{
FERREIRA FILIPA M.*, DELGADO M.L.**, SEIXAS LOPES A.M.** \& SAMPAIO SILVA M.L.
}

\section{Summary :}

The rearing of snails, intermediate hosts of Schistosoma haematobium, S. intercalatum, S. bovis and Fasciola hepatica is the first step to maintain the life cycle of these parasites in laboratory in order to have biological material for the different studies, namely on the systematic biology and immunodiagnostic of schistosomosis and fasciolosis.

According to the traditional method, the alga Oscillatoria formosa Bory (Cyanobacteria), principal food source for the snails, was cultivated in soil extract (Sampaio Xavier et al., 1968). However, it was sometimes very difficult to find the proper soil extract and the material was also contaminated by protozoa and fungi. In our work, using a new medium having as a base the Mineral Medium II (modified from Hughes et al., 1958) we found that $O$. formosa had a better growth response than in the soil extract medium. Snails fed on $O$. formosa reached three times the size of others at the same age, and they also reached sex maturity earlier, having more egg-masses per snail and, in addition, the rate of survival as well as the number of generations per year under laboratory conditions significantly increased. This culture was also easier to perform, and the axenic conditions easier to maintain.

KEY WORDS : O formosa Bory, new culture medium, intermediate hosts, schistosomosis, fasciolosis

T The rearing of the snails, intermediate hosts of some trematodes, parasites of human and domestic animals is very important to maintain the life cycle of these parasites in the laboratory in order to have enough biological material for experimental infections, systematic and biological studies, as well as antigen production for immunodiagnostic of some parasitic diseases.

Experiments carried out in our laboratory using the alga Oscillatoria formosa Bory (Cyanobacteria) as the principal food source for portuguese populations of Bulinus truncatus have showed that this new method

\footnotetext{
* Laboratório de Microbiologia de Águas (Water Microbiology laboratory).

** Laboratório de Parasitologia (Parasitology Laboratory), Instituto Nacional de Saúde Dr. Ricardo Jorge, National Health Institute), Largo $1^{\circ}$ de Dezembro, 4000 Porto, Portugal. Correspondence: M. Ferreira Filipa

Tel.: 00-351-222005043 - Fax: 00-351-223326001.

E-mail: icc.Imicinsaprt@mail.telepac.pt
}

Résumé : CONDITIONS DE CROISSANCE OPTIMALES D'OSCILLATORIA FORMOSA, PRINCIPAL ALIMENT DES HÔTES INTERMÉDIAIRES DE SCHISTOSOMOSE ET DE FASCIOLOSE, EN CULTURE AU LABORATOIRE L'élevage des mollusques hôtes interrnédiaires de Schistosoma haematobium, S. intercalatum, S. bovis et Fasciola hepatica est indispensable pour le maintien du cycle de ces parasites en laboratoire, de manière à permettre la réalisation des travaux en biologie et en immunodiagnostic.

Selon la méthode traditionnelle, la culture de l'algue Cyanophycée, Oscillatoria formosa, principal aliment des mollusques, est faite sur un extrait de terre (Sampaio Xavier et al., 1968). Toutefois, il est très difficile de trouver le sol approprié et ce matériel est facilement contaminé par des protozoaires et des champignons.

Dans le présent travail, les expériences démontrent qu'en utilisant le nouveau milieu liquide (OMN) élaboré à partir du Mineral Medium II modifié (Hughes et al., 1958), la croissance des Oscillatoria est plus importante qu'avec l'extrait de sol. Avec cette méthode, des mollusques du même âge triplent leurs dimensions, atteignent leur maturité sexuelle plus tôt. Le nombre de pontes est significativement augmenté de même que le taux de survie et le nombre de générations par année en laboratoire. Cette méthode est aussi plus facile à exécuter et plus facile à maintenir en conditions axéniques.

MOTS CLÉS : Oscillatoria formosa Bory, culture, hôtes intermédiaires, schistosomose, fasciolose.

is better than the method previously used in the laboratory and others methods described by Standen (1949), Azevedo et al. (1961), McClelland (1964), Najarin (1969), Claugher (1960). In fact, systematic findings on the snails fed with this alga not only kept the adult Bulinus alive but also made the new born to live beyond the critical growth period (Sampaio Xavier et al., 1968).

After these findings, O. formosa (initially provided from a pure culture, kindly given by Ollerenshaw, Agricultural Ministry in 1964) began to be cultivated in this laboratory in a large scale, as the principal source food for B. truncatus, and for other species like Planorbarius metidjensis, $B(\mathrm{Ph})$ globosus, Biomphalaria sp. and Lymnaea truncatula. However, the procedures used to cultivate this alga had some disadvantages. Although Oscillatoria was cultivated in a sterilised soil extract, it was easily contaminated with protozoa and fungi, and sometimes it was very difficult to find the proper soil extract. We think that it is interesting to perform 
a rich standard liquid medium to cultivate $O$. formosa, in order to have progressive stages of intermediate host populations of Schistosoma sp. and Fasciola sp.

In this study we tried to find an appropriate medium based upon the nutritional needs of $O$. formos $a$ and the intermediate hosts, minimising the stress problems and approaching the trophic relation between them. We created a new mineral medium based in the Mineral Medium $N^{\circ}$ II from Hughes et al. (1958) named OMNM (Oscillatoria mineral new medium).

\section{MATERIAL AND METHODS}

\section{BIOLOGICAL MATERIAL}

Snail population

Trn n our experiments we used B. truncatus from Coimbra (centre of Portugal). The snails were kept under the same laboratory conditions differing only in the way $O$. formosa was cultured. They were fed with the same O.formosa species but cultivated in two different ways:

- Procedure A - O. formosa Bory, from a plate cultivated in soil extract (according to the method described by Sampaio Xavier et al., 1968), designed as ML.

- Procedure B - O. formosa Bory cultivated in the new liquid tested medium, designed as OMNM (Oscillatoria rnineral new medium). Although there are lots of standard liquid medium to cultivate cyanobacteria and/or Oscillatoria, this OMNM is different from the others (and here is the innovation), because it had to be adjusted in order to eliminate some chemical molluscicides described by Combes \& McCullough (1982), Combes \& Cheng (1986) and Fenwick (1987) as being lethal to the snails.

The modification is mainly in the minor element solution. In this new medium, this solution is composed only by two elements instead of the original twelve elements. Also, in the final medium composition we add $10 \mathrm{ml} / \mathrm{L}$ of the new minor elements solution instead of the $0.08 \mathrm{ml} / \mathrm{L}$ used in the original mineral medium (Hughes et al., 1958) (Table I).

O. formosa is then cultivated in six litre batch-culture flasks and maintained at $20^{\circ}$, under continuous light from a cool white fluorescent lamp $\left(60 \mu \mathrm{E} / \mathrm{m}^{2} / \mathrm{s}\right)$ and aerated at a flow rate of $2 \mathrm{~L} / \mathrm{h}$. This new medium proved to be very successful in growth and snail breeding, as showed.

\begin{tabular}{cl}
\hline New minor elements solution & g/L \\
\hline 1. $\left(\mathrm{NH}_{4}\right)_{6} \mathrm{MO}_{7} \mathrm{O}_{24} 4 \mathrm{H}_{2} \mathrm{O}$ & 0.088 \\
2. $\mathrm{H}_{3} \mathrm{BO}_{3}$ & 3.1 \\
\hline
\end{tabular}

Table I. - New minor elements solution used in the OMNM.

\section{MiCROSCOPICAL OBSERVATIONS OF O. FORMOSA} TRICHOME

The Oscillatoria cells maintained in the two procedures were microscopically observed, every two days, based on the following parameters:

- contamination;

- time of the exponential growth phase (estimated by the tritium length in a period of time);

- morphological aspects of the trichome.

\section{EXPERIMENTAL REARING OF THE SNAILS}

Two groups of 100 snails each, with the same age and length, were kept in the two feeding procedures to determine the growth and sexual potential. These 200 snails were divided in five groups of 20 snails. Five groups were fed with Oscillatoria cultivated by procedure $\mathrm{A}$ and the other five groups, with Oscillatoria cultivated by procedure $\mathrm{B}$.

A second group of experiments was made with a total of 1,040 snails to determine the survival rate. The snails were distributed according to the eclosion date in a total of ten groups: five groups were fed with Oscillatoria cultivated by procedure $\mathrm{A}$ in a total of 520 snails and five groups were fed with Oscillatoria cultivated by procedure B ( 520 snails).

The evaluation parameters used to test the two procedures (A and $\mathrm{B}$ ) were:

. The snail growth was determined by measuring the shell diameter. During the first month, the snails were measured every two days with a micrometric ocular and then, weekly. The evaluation of the growth was based on the shell diameter of the snail until the end of the experience.

. Time of the maturation period (estimated as time of the first egg-mass): the maturation period was evaluated on shell diameter, age and number of eggmasses per snail. From the five groups of each procedure, we separated 20 snails from each group. In these two groups of 20 snails of each procedure, we annotated daily the number of egg-masses and the date corresponding to the flrst egg-mass of each group, until 30 days.

. Rate of survival: the number of survivals was related to the initial number of snails since the time that the experiment began until its end (eight months later).

\section{RESULTS}

$\mathrm{F}$ rom the results concerning the rate of survival, growth and sexual maturity of specimens of B. truncatus we observed that 130 days after having initiated our experiments we had a $96.3 \%$ of survivals, contrarily to the $75 \%$ obtained when we 
Fig. 1. - Survival rate of Bulinus truncatus fed with Oscillatoria cultivated by procedure A and fed with Oscillatoria cultivated by procedure $\mathrm{B}$.
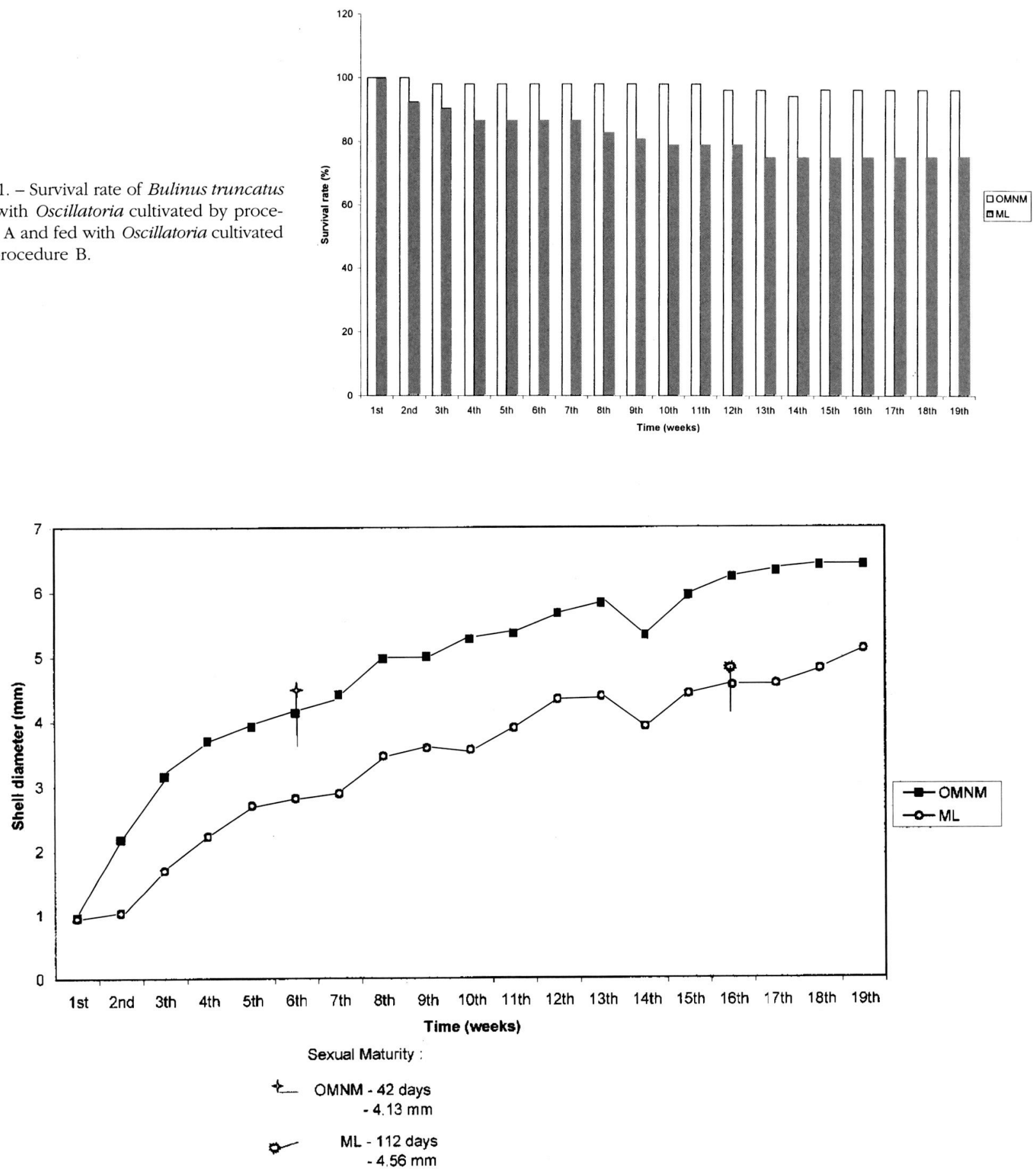

Fig. 2. - Growth results of Bulinus truncatus in the two tested media. 
used the procedure A (Fig. 1). In relation to the critical growth period, the first two weeks, we noticed a clear increase in the survival rate of the snails fed with $O$. formosa cultivated by procedure B (98\%), compared with the $86.5 \%$ survival rate value of the snails fed with $O$. formosa cultivated by procedure A. With this new medium we can reduce the initial risk of mortality observed with the anterior medium (procedure A).

Figure 2 expresses the growth results of the snails fed with $O$. formosa cultivated by the two procedures: A and $\mathrm{B}$.

The snails fed with Oscillatoria cultivated by procedure A had a slower growth with a shorter time of the exponential phase comparing with the snails fed with Oscillatoria cultivated by procedure B. Observing the same figure, we can also notice that the snails fed with Oscillatoria cultivated by procedure $\mathrm{B}$ had an increase of shell diameter from 0.95 to $6.42 \mathrm{~mm}$ contrarily to $5.12 \mathrm{~mm}$ in the snails fed with procedure A.

Comparing the sexual maturity of the two groups of snails, we observed that the snails fed with Oscillatoria cultivated by procedure $\mathrm{B}$ reached approximately the maturation period three times earlier than the snails fed with Oscillatoria cultivated by procedure A (a delay of ten weeks) (Fig. 2-vertical markers). From the Figure 2, we observed that the snails cultivated by OMNM reached the sexual maturity in 42 days at $4.13 \mathrm{~mm}$ of shell diameter. In relation to the number of egg-masses, we observed that the snails cultivated with this new medium (procedure B) had 970 eggmasses. On the other hand, the snails cultivated with Oscillatoria (procedure A) had 430 egg-masses, corresponding respectively to 1.6 egg-masses per snail per day and 0.71 egg-masses per snail per day.

\section{CONCLUSIONS}

F rom these results we concluded that this standard nutritional new liquid medium is not only very useful to maintain the intermediate hosts of Schistosoma and Fasciola in laboratory, but it is also more practical and has a better growth snail response than the traditional procedure (A). We eliminate certain minor elements, mentioned in the Mineral Medium II, because although these minor elements play a role in the Oscillatoria growth (for example, the cobalt is used to produce the B12 vitamin, the manganese is essential to free the oxygen from the photosystem in the photosynthesis) they do not influence the nutritional value of Oscillatoria sp. concerning the snail growth (Chu, 1942; Waris, 1953) but act as snail growth inhibitors and can even cause snail death (Fenwick, 1987). In our experiment we also tried other species of algae, like Chlorella sp. Gonium pectorale (Stein, 1966; Boz- niak, 1969) and other cyanobacteria as Nostoc sp. but with no success (Provasoli et al., 1960; Nichols et al., 1965; Carmichael et al., 1974; Rippka et al., 1979; Thiel et al., 1989). In fact, there are lots of work done concerning the cultivation of different species of algae in different liquid medium but no study is directly conducted to maintain intermediate snail host of some parasitosis. Generally the initial material is collected directly from the environment and in certain laboratories is maintained with artificial food, similar to the food used for the aquarium fishes or even chemically made. We think that Oscillatoria cultivated in OMNM, probably due to the similarity of what occurs in the natural conditions, creates a natural environment to these intermediate host snails and so permits to have enough material for other biological studies.

We clearly noticed advantages in using this new standard liquid OMNM for the growth of O. formosa used as the principal food source for the intermediate hosts of trematodes in order to improve the maintenance of Schistosoma and Fasciola life cycles. We observed that the snails not only triplicated their size but also reached the sexual maturity earlier. In addition, the number of egg-masses per snail increases significatively. With this new medium we can pass the critical growth period, permitting thus a large-scale production of these intermediate host species, so far difficult to keep under laboratory conditions.

Presently, this medium is used in our laboratory to feed not only Bulinus truncatus, but also B. globosus, B. forskali, Planorbarius metidjensis, Lymnaea truncatula and Biomphalaria glabrata.

\section{- ACKNOWLEDGEMENTS}

W e are in debt to Professor Combes for his technical assistance in the reading of this manuscript and Dr António Múrias from the University of Porto, Faculty of Science, Zoology department for his help in the graphical assistance and statistical advice.

\section{REFERENCES}

Azevedo J.F., Medeiros L.C.M., Fard M.M.C., Xavier M.L., Gandara A.F. \& Morms T. Os moluscos de água doce do Ultramar Português. III. Moluscos de Moçambique. Estudos, Ensaios e Docurnentos. Junta de Investigações de Ultramar, Lisboa, 1961, 88.

BOzNIAK E. Laboratory and field studies of phytoplancton communities. $\mathrm{Ph}$. D. Dissertation, Washington University, St. Louis, Missouri, 1969, 106 p.

Carmichael W.W. \& Gorham P.R. An improved method for obtaining axenic clones of planktonic blue-green algae. Journal of Phycology, 1974, 10, 238-240. 
Claugher D. The transport and laboratory culture of the snails intermediate hosts of Schistosoma haematobium. Annals of Tropical Medicine and Parasitology, 1960, 54, 333.

CHu S.P. The influence of the mineral composition of the medium on the growth of planktonic algae. Journal of ECO$\log y, 1942,30,284-325$.

Combes C. \& McCullough F. Le contrôle des mollusques vecteurs de schistosomes : résultats récents et perspectives. Revue Ibérique de Parasitologie, 1982, Spécial, 5-14.

Combes C. \& ChEng T.C. Control of biomedically important molluscs. Archives de l'Institut Pasteur d'Algérie, 1986, 55, 153-193.

FENWICK A. Experience in mollusciciding to control schistosomiasis. Parasitology Today, 1987, 3, 70-73.

Hughes E.O, Gorham P.R. \& Zehnder A. Toxicity of a unialgal culture of Microcystis aeruginosa. Canadian Journal of Microbiology, 1958, 4, 225-236.

MCClELland J.F.W. A method of breeding Bulinus (Physopsis) nasatus in the laboratory. Annals of Tropical Medicine and Parasitoly, 1964, 58, 264.

NAJARIN H.H. Maintenance and rearing of the snail Bulinus truncatus in laboratory. Journal of Parasitology, 1969, 46, 153.

Nichols H.W. \& BolD H.C. Trichosarcina polymorpha gen. et sp. nov. Journal of Phycology, 1965, I, 34-8.

Provasoli L. \& Pintner I.J. Artificial media for freshwater algae: problems and suggestions. In: The Ecology of Algae. Tryon C.A., Jr \& Hartman R.T. (eds.), Special Public. $\mathrm{N}^{\circ} 2$, Pymatuning Laboratory of Field Biology, Univ. Pittsburgh, 1960, 84-96.

Rippka R., Deruelles J., Waterbury J.B., Herdman M. \& StaNIER R.Y. Generic assignments, strains histories and properties of pure cultures of cyanobacteria. Journal of General Microbiology, 1979, III, 1-61.

Sampaio Xavier M.L., Fraga de Azevedo J. \& Avelino I. Importance d'Oscillatoria formosa Bory dans la culture au laboratoire des mollusques vecteurs de Schistosoma haematobium. Bulletin de la Société de Pathologie Exotique, 1968, 61, 52-66.

STANDEN O.D. Experimental schistosomiasis. I. The culture of the snail vectors Planorbis boissyi and Bulinus truncatus. Annals of Tropical Medicine and Parasitology, 1949, 43, 13.

STEIN J.R. Growth and mating of Gonium pectorale (Volvocales) in defined media. Journal of Phycology, 1966, 2, 2328.

Thiel T., Bramble J. \& Rogers S. Optimum conditions for growth of cyanobacteria on solid media. FEMS Microbiology Letters, 1989, 61, 27-32.

WARIS $H$. The significance for algae of chelating substances in the nutrient solutions. Physiology Plant, 1953, 6, 538543.

Reçu le 3 août 1999 Accepté le 30 juin 2000 